\title{
Improvement of cultivation technology of winter durum wheat in the conditions of the Kabardino-Balkarian Republic
}

\author{
A.Yu. Kishev, K.Z. Berbekov, Z.S. Shibzukhova, Z.-G.S. Shibzukhov", and N.I. Mamsirov \\ Federal State Budgetary Educational Institution of Higher Education "Kabardino-Balkarian State \\ Agrarian University named after V.M. Kokov"
}

\begin{abstract}
Plants' nutritional elements have great opportunities to increase the yield of cereals, which contribute to the activation of initial growth and accelerate plants' development, stimulate the plumpness and grain formation, increase grain resistance to adverse soil and climatic conditions, increase productivity and biochemical qualitative indicators. In modern conditions, designing a technological system for regulating the growth and development of winter durum wheat by complex mineral fertilizers' application in steppe conditions of CBR is very relevant. The positive influence of nutritional elements on the development and root system of cereals has been revealed. Seeds of modern durum wheat varieties have high nutritional and taste qualities. The main direction of increasing winter durum wheat production is the introduction of new high-yielding varieties into production and their cultivation according to intensive technology with reasonable doses and norms of nutrients.
\end{abstract}

\section{Introduction}

Currently, the problem of increasing the yield of grain crops with high-quality grain has significantly worsened and has gained an important national economic importance. "Biologization of agriculture, rational use of arable land, use of fertilizer systems on a biological basis, selection of the best precursors in crop rotation and the use of new highyielding varieties and hybrids of grain crops largely determine the solution to the problem of increasing the yield of cereals" [5,6,7].

In the current economic situation, intensive cultivation technology for winter durum wheat has become unacceptable for most agricultural enterprises. Therefore, it became necessary to find an alternative approach to the development of various technology elements, the introduction of which would allow for stable high yields and competitive products with soil fertility preservation through the inclusion of biogization elements and resource conservation $[3,4]$.

Since the late seventies in the North Caucasus, thanks to winter soft wheat selection food grain was produced only due to this type of wheat. The natural and climatic conditions

\footnotetext{
* Corresponding author: konf07@mail.ru
} 
of the North Caucasus are most favorable for this wheat variety and allow to obtain record harvests compared to all other known regions of Russia suitable for growing wheat.

In $70-80$ s, the North Caucasus grew over 0.6 million tons of first-grade durum wheat and more than half of the harvest was sent for export.

The value we get from durum wheat cannot be replaced by soft wheat. Cereals, pasta, biscuits, pita bread and other products derived from durum wheat grain have consistent high quality.

On this basis, it should be borne in mind that therefore in some countries there is a law prohibiting the production of pasta from soft wheat.

A lot of products can be obtained from durum wheat, which are very useful and necessary for children as a dietary product. They naturally have high content of protein, amino acids, and a lower starch content. It should be noted that it also contains dextrins in large quantities.

In the Russian Federation, the situation with the domestic market purchases of durum, strong and valuable varieties have especially deteriorated. Thus, purchases of durum wheat decreased from 0.86 million tons in 2010 to 0.62 million tons in 2011-2015, or $29 \%$. In 2016-2020, even less was purchased.

In recent years, winter durum wheat is grown in the Kabardino-Balkarian Republic. So, in 2019-2020 in the steppe zone in the Prokhladnensky district of the CBR, $45 \mathrm{cwt} / \mathrm{ha}$ of durum wheat grain was obtained, the yield of which is no less than of the strong varieties of winter soft.

Soil-climatic conditions of CBR are quite favorable for growing winter durum wheat. This was one of the reasons why we had a need to select and study new varieties of durum wheat and introduce them into production, as well as to improve the basic technological techniques of durum wheat growing.

Experiments were laid in the steppe zone of the Kabardino-Balkarian Republic. The precursor during the years of research was peas and maize for silage. After precursors' harvesting, the plot was disked in two directions with further ploughing to a depth of 20-22 $\mathrm{cm}$ followed by surface treatment: as weeds appeared, LDG skim plow processing - 10 in the unit with BDT disc harrows - 7.0.

Sowing of the studied varieties of winter wheat was carried out in a narrow rows method with a sowing rate of 5.5 million of germinated grains $(240 \mathrm{~kg} / \mathrm{ha})$. The experiment was carried out on the $25 \mathrm{~m}^{2}$ plots. The experiment's repetition was four-fold.

Agrochemical characteristics of the soil, humus content was determined according to I.V. Tyurin, the degree of base saturation, the sum of the absorbed bases, the $\mathrm{pH}$ of the salt extraction was determined according to generally accepted methods. The accumulation of dry matter by the plant was considered by the phases of growth and development of plants. Leaf area was determined by excision method (out of 100 excisions from 10 plants in three times repetition). The area of leaves was calculated per plant and per unit of sowing area [1].

As research objects, we decided to choose new varieties of winter durum wheat - Oniks, Diona and Kristella.

The aim of the research was to optimize elements of increasing productivity by calculating and identifying optimal doses and norms of mineral fertilizers for winter durum wheat and recommend production of the results of our study to optimize methods and elements to improve the yield of winter durum wheat varieties in the CBR.

\section{Experimental conditions and methods of research}

In the steppe zone of the Kabardino-Balkarian Republic. The Republic first studied the influence of various mineral fertilizers and their doses on the growth and formation, yield, 
and grain quality of the latest winter durum wheat varieties. A relationship was obtained between the yield and quality of winter durum wheat varieties and the availability and possibility of obtaining the used components of mineral nutrition.

Practical value. The use of proven technologies, ensuring deeper use of various and new varieties of winter durum wheat in certain soil and climatic conditions of our republic will allow to increase the yield to 41-46 cwt/th.ha ha with the best technological qualities of grain.

The problem of cultivating winter durum wheat has been of interest to farmers since long ago. Pasta is obtained from it, as durum wheat grains contain $2-5 \%$ more protein than soft wheat. Protein contained in durum wheat has a higher content of lysine, the amount of which reaches $4.21 \%$ or up to $0.563 \mathrm{mg}$ per $100 \mathrm{~g}$ of grain.

In the processing industry, the threshing of durum wheat grain produces a larger number of crumbs, which are known to be an exceptional product and raw material for producing pasta of the highest grade, noodles, spaghetti, and other products characterized by greater strength, keeping quality and transportability, pleasant to taste and not deforming when cooking. "Flour derived from durum wheat is usually used as an improver and increases the nutritional value of bread: if $25-35 \%$ of durum flour is added to the flour from weak wheat varieties, bread turns out to be more nutritious and tasty and does not stale for a longer time. Historically, durum wheat is one of the most ancient crops on Earth. Dating back to the 4th millennium BC, seeds of this wheat were found in southern Ukraine, by the 3rd millennium - in Transcaucasia (Azerbaijan), to the X-XII centuries A.D. - in the Don region." [1].

\section{Research results}

The results of our experimental studies show that leaf area, photosynthetic potential and net photosynthesis productivity are in most cases determined by mineral fertilizers, their doses and biological characteristics of varieties (table 1). It can be said that when increasing the nutrients by using mineral fertilizers in the dose $\mathrm{N}_{60 \mathrm{P}}{ }_{60} \mathrm{~K}_{40} \mathrm{~kg} / \mathrm{ha}$, the maximum leaf area for earing period amounted to 47.2 thousand $\mathrm{m}^{2} /$ ha, with control -41.8 .

The highest indicator on the sheet are of the Oniks variety amounted to 48.7 thousand $\mathrm{m}^{2} /$ ha, on the control plot -42.5 thousand $\mathrm{m}^{2} /$ ha. Kristella variety -45.3 and 40.1 thousand $\mathrm{m}^{2} /$ ha respectively.

But the highest photosynthesis indicators in winter durum wheat varieties were obtained by the introduction of $\mathrm{N}_{90} \mathrm{P}_{120} \mathrm{~K}_{40} \mathrm{~kg} / \mathrm{ha}$.

The highest indicator of NPP (net photosynthesis productivity) was obtained with the largest leaf area in Oniks variety when applying increased fertilizer norms and amounted to 50.1 thousand $\mathrm{m}^{2} / \mathrm{ha}$, NPP $-4.4 \mathrm{~g} / \mathrm{m}^{2}$ per day, per $1000 \mathrm{pcs}$. PP received $2.1 \mathrm{~kg}$ of grain.

Table 1. Dependence of photosynthetic activity indicators on the use of different mineral fertilizers doses (average for 2018-2020)

\begin{tabular}{|c|c|c|c|c|}
\hline $\begin{array}{l}\text { Experimental } \\
\text { options }\end{array}$ & $\begin{array}{l}\text { Indicator of } \\
\text { leaf area } \\
\text { th. } \mathrm{m}^{2} / \text { ha }\end{array}$ & $\begin{array}{l}\text { PP indicator, } \mathrm{M} \text {. } \\
\mathrm{m}^{2} \text {, day/ha }\end{array}$ & $\begin{array}{l}\text { NPP indicator, } \\
\mathrm{g} / \mathrm{m}^{2} \\
\text { day }\end{array}$ & $\begin{array}{l}\text { Productivity } \\
1 \text { t/unit PP per } \\
\mathrm{kg} \text { of grain }\end{array}$ \\
\hline \multicolumn{5}{|c|}{ Diona } \\
\hline Control & 41.8 & 2.39 & 3.5 & 1.2 \\
\hline $\begin{array}{ll} & \mathrm{N}_{60} \mathrm{P}_{90} \mathrm{~K}_{4} \\
& \end{array}$ & 47.2 & 2.53 & 3.9 & 1.7 \\
\hline $\begin{array}{ll} & \mathrm{N}_{90} \mathrm{P}_{120} \mathrm{~K} \\
60 & \end{array}$ & 49.3 & 2.67 & 4.1 & 1.9 \\
\hline \multicolumn{5}{|c|}{ Kristella } \\
\hline Control & 40.1 & 2.21 & 3.3 & 1.1 \\
\hline
\end{tabular}




\begin{tabular}{|c|c|c|c|c|}
\hline $\begin{array}{ll} & \mathrm{N}_{60} \mathrm{P}_{90} \mathrm{~K}_{4} \\
0 & \end{array}$ & 45.3 & 2.43 & 3.4 & 1.4 \\
\hline $\begin{array}{ll} & \mathrm{N}_{90} \mathrm{P}_{120} \mathrm{~K} \\
60 & \end{array}$ & 47.8 & 2.61 & 3.7 & 1.6 \\
\hline \multicolumn{5}{|c|}{ Oniks } \\
\hline Control & 42.5 & 2.41 & 3.6 & 1.3 \\
\hline $\mathrm{N}_{0} \mathrm{~N}_{60} \mathrm{P}_{90} \mathrm{~K}_{4}$ & 48.7 & 2.65 & 3.9 & 1.8 \\
\hline $\begin{array}{ll}{ }_{60} & \mathrm{~N}_{90} \mathrm{P}_{120} \mathrm{~K}\end{array}$ & 50.1 & 2.87 & 4.4 & 2.1 \\
\hline
\end{tabular}

As can be seen from the table data, the option with the mineral fertilizers' use in the dose $\mathrm{N}_{90} \mathrm{P}_{120} \mathrm{~K}_{60}$ was the best, because the indicators of PP and NPP were the highest, and Oniks variety was positively distinguished among the varieties with values of 2.87 and 4.4 respectively. Also, the wheat plant formed the largest leaf surface area on this option.

To realize the high potential of durum wheat, it is necessary to provide the best soil and climatic conditions in terms of mineral nutrition. A distinctive feature of the new studied durum wheat varieties is that the lodging level decreases with the increase in the mineral nutrition level, which is the reason for the increase in the yield gain. (Table 2).

Thus, the studied variety Diona in the control option had a 9.0 lodging point, and when applying fertilizers in the dose $\mathrm{N}_{90} \mathrm{P}_{120} \mathrm{~K}_{40}-5.1$, Kristella - 7.2 and 5.1 points respectively, Oniks - 9.0 and 5.1 points.

Strangely, from our research it was revealed that the disease rate of winter durum wheat increased proportionally with the increase in fertilizers use, especially nitrogen.

Table 2. Change in the susceptibility index of winter durum wheat plant disease depending on the fertilizer used (average for 2018-2020 years).

\begin{tabular}{|c|c|c|c|}
\hline \multirow[t]{2}{*}{ Indicators } & \multicolumn{3}{|c|}{ Doses, $\mathrm{kg} / \mathrm{ha}$ a.s. } \\
\hline & Control & $\mathrm{N}_{60} \mathrm{P}_{60} \mathrm{~K}_{40}$ & $\mathrm{~N}_{90} \mathrm{P}_{120} \mathrm{~K}_{40}$ \\
\hline \multicolumn{4}{|c|}{ Diona } \\
\hline $\begin{array}{l}\text { Lodging degree, } \\
\text { (points) }\end{array}$ & 9.0 & 7.2 & 5.1 \\
\hline $\begin{array}{l}\text { Powdery mildew, } \\
\text { (points) }\end{array}$ & 0.2 & 2.3 & 3.2 \\
\hline $\begin{array}{l}\text { Brown rust, } \\
\text { (points) }\end{array}$ & 2.2 & 3.2 & 4.1 \\
\hline Ear fusarium, $(\%)$ & 0.4 & 0.8 & 0.8 \\
\hline \multicolumn{4}{|c|}{ Kristella } \\
\hline $\begin{array}{l}\text { Lodging degree, } \\
\text { (points) }\end{array}$ & 7.2 & 7.2 & 5.1 \\
\hline $\begin{array}{l}\text { Powdery mildew, } \\
\text { (points) }\end{array}$ & 0.2 & 2.3 & 3.2 \\
\hline $\begin{array}{l}\text { Brown rust, } \\
\text { (points) }\end{array}$ & 1.4 & 3.2 & 4.1 \\
\hline Ear fusarium, (\%) & 0.5 & 0.8 & 1.1 \\
\hline \multicolumn{4}{|c|}{ Oniks } \\
\hline $\begin{array}{l}\text { Lodging degree, } \\
\text { (points) }\end{array}$ & 9.0 & 5.1 & 5.1 \\
\hline $\begin{array}{l}\text { Powdery mildew, } \\
\text { (points) }\end{array}$ & 1.5 & 3.2 & 3.3 \\
\hline $\begin{array}{l}\text { Brown rust, } \\
\text { (points) }\end{array}$ & 1.5 & 3.2 & 4.1 \\
\hline Ear fusarium, (\%) & 0.5 & 0.9 & 0.9 \\
\hline
\end{tabular}


Literary data studied and many scientists argue that the better a man creates conditions for growth and development, the better the structure of the crop [1]. "Naturally, the use of mineral fertilizers increases the structure of the crop" [2]. By studying the structure of the winter durum wheat yield, scientists determined that the degree of nutrition is suitable for the structure formation process. Experiments show that the studied doses and norms of mineral nutrition increased such indicators as the ear length by $0.4-0.5 \mathrm{~cm}$ compared to control, and with increased nutrients the percentage of grain content in the ear increases by 2,2-2,5 grains on the option where double application of nutrients was used.

Among the studied varieties in all experiments, Oniks variety was positively different with the best indicators of yield.

Table 3. Indicators of the yield structure of winter durum wheat depending on the nutrients level (average for 2018-2020)

\begin{tabular}{|c|c|c|c|}
\hline \multirow[t]{2}{*}{ Indicators } & \multicolumn{3}{|c|}{ Fertilizers (kg/ha a.s.) } \\
\hline & Control & $\mathrm{N}_{60} \mathrm{P}_{90} \mathrm{~K}_{40}$ & $\mathrm{~N}_{90} \mathrm{P}_{120} \mathrm{~K}_{60}$ \\
\hline \multicolumn{4}{|c|}{ Diona } \\
\hline Product. till.capacity & 1.7 & 1.8 & 1.8 \\
\hline Number of grains & 30.1 & 30.3 & 30.6 \\
\hline Number of spikelets & 20.3 & 20.8 & 21.2 \\
\hline $\begin{array}{l}\text { Number of grains from } \\
1 \text { plant }\end{array}$ & 48.4 & 49.3 & 49.9 \\
\hline $\begin{array}{l}\text { Weight of grain from } 1 \\
\text { plant, g }\end{array}$ & 1.9 & 2.1 & 2.2 \\
\hline \multicolumn{4}{|c|}{ Kristella } \\
\hline Product. till.capacity & 1.2 & 1.4 & 1.5 \\
\hline Number of grains & 29.2 & 30.1 & 31.2 \\
\hline Number of spikelets & 19.5 & 20.6 & 21.4 \\
\hline $\begin{array}{l}\text { Number of grains from } \\
1 \text { plant }\end{array}$ & 39.9 & 40.1 & 40.8 \\
\hline $\begin{array}{l}\text { Weight of grain from } 1 \\
\text { plant, } g\end{array}$ & 1.8 & 2.2 & 2.4 \\
\hline \multicolumn{4}{|c|}{ Oniks } \\
\hline Product. till.capacity & 1.7 & 1.9 & 2.1 \\
\hline Number of grains & 29.6 & 30.7 & 32.1 \\
\hline Number of spikelets & 21.9 & 22.3 & 22.8 \\
\hline $\begin{array}{l}\text { Number of grains from } \\
1 \text { plant }\end{array}$ & 47.2 & 49.3 & 50.1 \\
\hline $\begin{array}{l}\text { Weight of grain from } 1 \\
\text { plant, g }\end{array}$ & 1.7 & 1.9 & 2.0 \\
\hline
\end{tabular}

As a result, according to the calculation results of winter durum wheat varieties' yield, we came to the conclusion that the considered technological techniques had a significant impact on plant productivity indicators (table 4). Scientists such as D.N. Pryanishnikov consider the impact on the soil by mineral fertilizers application method as the main factor, due to which the yield and consequent obtained products' quality is increased.

Determination of the relationship of the obtained crop, its quality and various norms and composition of introduced mineral fertilizers in our proposed soil and climatic conditions allows to study and obtain new possibilities of using mineral fertilizers in certain areas, considering not only the planned harvest, but also its quality.

Presented in table 4, the results obtained show excellent results on the effectiveness of mineral fertilizers application. For example, it can be said that the use of $\mathrm{N}_{60} \mathrm{P}_{90} \mathrm{~K}_{40} \mathrm{~kg}$ a.s. contributed to an increase in grain yield value compared to the control by 2,3-3.9 cwt/ha. 
Table 4. Indicators of winter durum wheat yield depending on different nutrients doses (average for 2018-2020)

\begin{tabular}{|c|c|c|c|c|c|c|}
\hline \multirow[t]{2}{*}{ Variety } & \multirow{2}{*}{$\begin{array}{l}\text { Mineral } \\
\text { nutrition level, } \\
\text { kg a.s./ha }\end{array}$} & \multicolumn{3}{|c|}{ Yield, cwt/ha } & \multirow{2}{*}{$\begin{array}{l}\text { Average } \\
\text { for } 3 \\
\text { years }\end{array}$} & \multirow{2}{*}{$\begin{array}{l}\text { Gain } \\
\text { cwt/ha to } \\
\text { control }\end{array}$} \\
\hline & & 2018 & 2019 & 2020 & & \\
\hline \multirow[t]{4}{*}{ Diona } & Control & 27.8 & 30.3 & 23.7 & 27.2 & - \\
\hline & $\mathrm{N}_{60} \mathrm{P}_{90} \mathrm{~K}_{40}$ & 28.0 & 32.8 & 33.2 & 31.3 & 4.1 \\
\hline & $\mathrm{N}_{60} \mathrm{P}_{120} \mathrm{~K}_{60}$ & 34.0 & 36.6 & 34.2 & 34.9 & 7.7 \\
\hline & $\mathrm{LCD}_{05}, \mathrm{cwt} / \mathrm{ha}$ & 3.6 & 2.9 & 3.7 & & \\
\hline \multirow[t]{4}{*}{ Kristella } & Control & 25.8 & 22.1 & 27.8 & 25.2 & - \\
\hline & $\mathrm{N}_{60} \mathrm{P}_{90} \mathrm{~K}_{40}$ & 26.7 & 23.2 & 31.2 & 27.0 & 1.8 \\
\hline & $\mathrm{N}_{60} \mathrm{P}_{120} \mathrm{~K}_{60}$ & 29.4 & 23.9 & 33.0 & 28.7 & 3.5 \\
\hline & $\mathrm{LCD}_{05}, \mathrm{cwt} / \mathrm{ha}$ & 2.7 & 2.3 & 3.6 & & \\
\hline \multirow[t]{4}{*}{ Oniks } & Control & 25.7 & 32.8 & 36.1 & 31.5 & - \\
\hline & $\mathrm{N}_{60} \mathrm{P}_{90} \mathrm{~K}_{40}$ & 27.7 & 36.5 & 39.5 & 34.5 & 3.0 \\
\hline & $\mathrm{N}_{60} \mathrm{P}_{120} \mathrm{~K}_{60}$ & 33.7 & 36.7 & 40.6 & 37.0 & 5.5 \\
\hline & $\begin{array}{l}\mathrm{LCD}_{05}, \\
\mathrm{cwt} / \mathrm{ha}\end{array}$ & 3.8 & 3.5 & 3.3 & & \\
\hline
\end{tabular}

According to the results of our studies, it is evident that the highest grain yield was obtained when applying the maximum indices of nutrients in the dose $\mathrm{N}_{90} \mathrm{P}_{120} \mathrm{~K}{ }_{60}$ a.s. $\mathrm{kg} / \mathrm{ha}$. This figure was more than control by $3.5-7.5 \mathrm{cwt} / \mathrm{ha}$.

The highest grain yield for the entire period of research was noted in Oniks variety $37.0 \mathrm{cwt} / \mathrm{ha}$.

Also, the use of mineral fertilizers significantly increased the technological properties of durum wheat grain (table 5). Many scientists have already proven that the influence of mineral fertilizers on the protein content and chemical composition of wheat grain is quite large.

This is also evident from the data we have received; the use of mineral fertilizers has a strong impact on the technological properties of winter durum wheat varieties. The protein content in the second option became larger when compared with control by $0.4-0.6 \%$, in the third option - by $0.8-1.1 \%$. The variation in the raw gluten content indicator was from $33.1 \%$ in control and up to $37.6 \%$ in the options with the use of nutrients. The use of these very nutrients also increased the mass of grain from $743 \mathrm{~g} / 1$ in control to $782 \mathrm{~g} / 1$ in options with fertilizer application and naturally, the weight indicator of 1000 grains from 41.0 to $44.5 \mathrm{~g}$. The output of glassy grains increased from 92 to $94-96 \%$.

The effect of mineral fertilizers can also be seen in terms of strength; pasta derived from wheat grains grown on fertilized soils was stronger than on unfertilized ones.

In the second and third experimental options, high protein and gluten yield was obtained in Kristella variety.

Table 5. Technological indicators and pasta qualities of new winter durum wheat varieties depending on the level of nutrients (average for 2018-2020)

\begin{tabular}{|l|c|c|c|}
\hline \multirow{2}{*}{ Quality traits } & \multicolumn{3}{c|}{ Doses, kg/ha a.s. } \\
\cline { 2 - 4 } & Control & $\mathrm{N}_{60} \mathrm{P}_{90} \mathrm{~K}_{40}$ & $\mathrm{~N}_{90} \mathrm{P}_{120} \mathrm{~K}_{60}$ \\
\hline \multicolumn{3}{|c|}{ Diona } \\
\hline Weight of 1000 grains, g & 43.5 & 44.1 & 44.3 \\
\hline Cup weight, g/ & 755 & 776 & 782 \\
\hline Vitreousness index, \% & 94 & 96 & 96 \\
\hline Protein, \% & 12.8 & 13.2 & 13.9 \\
\hline
\end{tabular}




\begin{tabular}{|l|c|c|c|}
\hline Gluten, \% & 33.1 & 34.3 & 37.6 \\
\hline Gluten group & II & II & II \\
\hline Strength, g & 798 & 802 & 811 \\
\hline Color & yellow & yellow & bright yellow \\
\hline Overall score, points & 4.0 & 4.5 & 4.5 \\
\hline \multicolumn{3}{|c|}{ Kristella } \\
\hline Weight of 1000 grains, g & 42.5 & 43.1 & 44.5 \\
\hline Cup weight, g/ & 748 & 765 & 771 \\
\hline Vitreousness index, \% & 92 & 95 & 96 \\
\hline Protein, \% & 13.1 & 13.9 & 14.4 \\
\hline Gluten, \% & 32.8 & 35.2 & 37.3 \\
\hline Gluten group & II & II & II \\
\hline Strength, g & 795 & 823 & 827 \\
\hline Color & yellow & bright yellow & bright yellow \\
\hline Overall score, points & 4.0 & 4.5 & 4.5 \\
\hline \multicolumn{2}{|c|}{ Oniks } & \multicolumn{1}{|c|}{} \\
\hline Weight of 1000 grains, g & 41.0 & 42.4 & 43.1 \\
\hline Cup weight, g/ & 743 & 755 & 757 \\
\hline Vitreousness index, \% & 94 & 96 & 96 \\
\hline Protein, \% & 13.3 & 13.8 & 14.1 \\
\hline Gluten, \% & 32.5 & 35.8 & 36.7 \\
\hline Gluten group & II & II & II \\
\hline Strength, g & 802 & 805 & 811 \\
\hline Color & yellow & yellow & bright yellow \\
\hline Overall score, points & 4.0 & 4.5 & 4.5 \\
\hline
\end{tabular}

\section{Conclusions}

1. As a research result, it can be said that Oniks variety has the best data on all the studied parameters. But most importantly, the maximum yield of $40.6 \mathrm{cwt} / \mathrm{ha}$ was obtained in this variety when applying nutrients in the dose $\mathrm{N}_{90} \mathrm{P}_{120} \mathrm{~K}_{60}$

2. According to technological indicators and pasta qualities of the resulting crop, Oniks variety also showed the highest data and naturally, on the option when applying nutrients in the dose $\mathrm{N} 90 \mathrm{P}_{120} \mathrm{~K}_{60}$

3. Of the tested winter durum wheat varieties according to the set of indicators, Onyx was the best.

\section{References}

1. A.Ch. Udjuhu, N.I. Mamsirov, A.Yu. Kishev, Yu.A. Chumachenko, Z.Sh. Daguzhieva, Fundamentals of agronomy, Textbook for students in specialities 35.03.04 Agronomy, 35.04.04 Agronomy, 35.03.07 Technology of production and processing of agricultural products, 35.06.01 Agriculture, 148 - 164, 212-253 (2018)

2. I.M. Khanieva, A.Yu. Kishev, Z.S. Shibzukhov, T.B. Zherukov, Agrarian Russia, 1, 19-23 (2019)

3. F. Rossini, M.E. Provenzano, F. Sestili, R. Ruggeri, Agronomy, 8(9), 189, (2018)

4. L.Li Zhao, L. Cai, H. (...), R.W. Malone, C. Zhang, Agronomy Journal, 111(2), 482495 (2019)

5. E.N. Didanova, M.S. Sidakova, A.Y. Kishev, R.Z. Abdulkhalikov, E3S Web of 
Conferences. 222, 22 (2020)

6. Z.-G. Shibzukhov, K. Nazranov, E. Didanova, M. Orzalieva, B. Nazranov, E3S Web of Conferences, 222, 22 (2020).

7. I.M. Khanieva, S.A. Bekuzarova, R.Z. Abdulkhalikov, A.L. Boziev, Yu.M. Shogenov, E3S Web of Conferences, 222, 22 (2020) 